\title{
РАСКРЫТИЕ ИНФОРМАЦИИ КАК ФОРМА ОБЕСПЕЧЕНИЯ ДОСТУПА К ИНФОРМАЦИИ, СОСТАВЛЯЮЩЕЙ ОБЩЕСТВЕННЫЙ ИНТЕРЕС
}

Аннотация: Информация, представляющая общественный интерес, должна быть доступна общественности. Основными обладателями такого рода информации являются органы государственной власти и местного самоуправления. Раскрытие информации, представляющей общественный интерес, при условии, что доступ к ней не ограничен законом, является обязанностью соответствующих органов. Тем самым обеспечивается право граждан на доступ к информации. Это право положено в основу такого правового явления, как общественный контроль вместе с правом на участие в управлении делами государства. Путём сравнительного анализа положений нормативных правовых актов, посвящённых регулированию процедур общественного контроля и процедур раскрытия информации, проводится исследование права на доступ к информации как правовой основы общественного контроля. Особенности понятия "раскрытие информации», его роли в информационном обмене, а также выявленные признаки этой фрормы обеспечения доступа к информации, позволяют сделать вывод о необходимости нормативного закрепления этого понятия. Также предлагается определение «общественные интересы» как критерия информации, подлежащей раскрытию, а также основы общественного контроля.

Ключевые слова: раскрытие информации, право на информацию, общественный контроль, общественный интерес, открытые данные, информационная открытость, предоставление информации, распространение информации, общественные обсуждения, информационная система. DOI: 10.7256/1994-1471.2014.5.11314

$\Pi$ ервостепенное значение для гарантии обеспечения права доступа к информации является необходимость признания со стороны государства, что основные обладатели общественно значимой информации государственные органы и органы местного самоуправления - должны использовать эту информацию в интересах своих граждан.

Презумпция информационной открытости основывается на положении о том, что информация, составляющая общественный интерес, должна быть доступна общественности. Реализация свободного потока информации напрямую связана с правом на информацию и основанном на нем общественном контроле.

Общественный контроль - это контроль со стороны многонационального народа и гражданского общества РФ, политических партий и общественных объединений, профсоюзов, средств массовой информации, различных социальных групп и сообществ гражданского общества за деятельностью государственных

и муниципальных органов власти ${ }^{1}$. 0 н проявляется в сложной системе сдержек и противовесов при реализации принципа разделения властей, в открытости и доступности государственных органов, в их подотчетности всему народу, в их взаимодействии со СМИ, институтами гражданского общества ${ }^{2}$.

Информационная прозрачность деятельности государственных органов, с одной стороны, подстегнет граждан внимательней следить за их деятельностью, с другой стороны, не оставит должностным лицам места для коррупционного маневра или элементарной халатности.

В Федеральном законе «Об информации, информационных технологиях и о защите

\footnotetext{
Пылин В. В., Пылин С. В. Государственный и муниципальный контроль: учеб. пособие СПб.: Изд-во Политехн. ун-та, 2006. - С. 13.

Новиков А. В. Контроль в социально-политической системе российского общества, М.: Соврем. Экономика и право, 2005. - С. 23.
}

(C) Околёснова Ольга Алексеевна

* Научный сотрудник, НИУ Высшая школа экономики, Научно-методический центр «Кафедра ЮHECKO»

[phibe_pepsi@mail.ru]

119017, Россия, г. Москва, ул. М. Ордынка, д. 17. 
информации» ${ }^{3}$ заложены основные положения права на информацию. Подчеркивается свобода поиска и получения любой информации в любых формах и из любых источников при условии соблюдения требований закона.

Этим же законом предусмотрены две формы доступа к информации: предоставление и распространение. При этом под предоставлением информации понимаются действия, направленные на получение информации определенным кругом лиц или передачу информации определенному кругу лиц; распространение информации - действия, направленные на получение информации неопределенным кругом лиц или передачу информации неопределенному кругу лиц.

Таким образом, доступ к информации о деятельности органов власти должен обеспечиваться не только возможностью получить такую информацию по запросу, но и обязанностью соответствующих органов власти распространять определенную ее часть среди неопределенного (неограниченного) круга лиц.

Но в российском законодательстве наряду с вышеописанными формами обеспечения доступа к информации также используется термин «раскрытие информации». Обладатель информации вправе определять режим доступа к такой информации. При этом ограничить доступ к такой информации обладатель может в любых целях, которые могут принести ему выгоду любого характера. Но в силу ряда обстоятельств может потребоваться раскрытие информации ее обладателем. К отличительным признакам раскрытия информации можно отнести следующие. Во-первых, раскрытие всегда происходит на основании требований нормативного правового акта. Во-вторых, доступ к раскрываемой информации не ограничен положениями нормативного правового акта, а лишь волей обладателя такой информации в силу какой бы то ни было необходимости. В-третьих, раскрытие всегда производится с определенной целью - обеспечение общественных интересов.

Общественные интересы - явление, получившее широкое распространение в отечественном правовом поле, при этом, не имея четко закрепленного определения. Определения понятия «общественные интересы» имеет принципиальное правовое значение. Общественные интересы являются одним их ключевых понятий в системе общественного контроля как основной критерий его проведения. Общественный инте-

Федеральный закон от 27.07.2006 № 149-Ф3 (ред. от 21.07.2011) «Об информации, информационных технологиях и о защите информации» // Собрание законодательства РФ. 2006, № 31 (1 ч.), ст. 3448. рес как потребность в информации есть прямое следствие права на информацию. Эта потребность должна удовлетворяться при осуществлении процедур общественного контроля.

Таким образом, целесообразно определить общественный интерес как потребность неопределенного круга лиц в получении информации со стороны государственных органов или иных обладателей такой информации в целях реализации и защиты охраняемых Конституцией РФ благ и ценностей.

Требования раскрытия информации можно встретить во многих нормативных правовых актах: Федеральный закон «О рынке ценных бумаг» ${ }^{4}$ (Глава 7. 0 раскрытии информации на рынке ценных бумаг); Федеральный закон «Об ипотечных ценных бумагах» ${ }^{5}$ (Статья 37. Раскрытие и предоставление информации об облигациях с ипотечным покрытием); Федеральный закон «Об особенностях эмиссии и обращения государственных и муниципальных ценных бумаг» ${ }^{6}$ (Статья 12. Раскрытие информации о государственных и муниципальных ценных бумагах); Федеральный закон «0 противодействии неправомерному использованию инсайдерской информации и манипулированию рынком и о внесении изменений в отдельные законодательные акты Российской Федерации» ${ }^{7}$ (Статья 15. Раскрытие информации Банком России); Федеральный закон «0 жилищных накопительных кооперативах» ${ }^{8}$ (Статья 21. Порядок раскрытия информации кооперативом); Федеральный закон «Об основах регулирования тарифов организаций коммунального комплекса» ${ }^{9}$ (Статья 3.1. Стан-

4 Федеральный закон от 22.04 .1996 № 39-Ф3 (ред. от
28.12.2013) «О рынке ценных бумаг» // Собрание законодательства РФ. 1996. № 17. Ст. 1918.

Федеральный закон от 11.11.2003 № 152-Ф3 (ред. от 23.07.2013) «Об ипотечных ценных бумагах» // Собрание законодательства РФ. 2003. № 46 (ч. 2). Ст. 4448.

6 Федеральный закон от 29.07.1998 № 136-Ф3 (ред. от 14.06.2012) «Об особенностях эмиссии и обращения государственных и муниципальных ценных бумаг» // Coбрание законодательства РФ. 1998. № 31. Ст. 3814.

Федеральный закон от 27.07.2010 № 224-Ф3 (ред. от 23.07.2013) «О противодействии неправомерному использованию инсайдерской информации и манипулированию рынком и о внесении изменений в отдельные законодательные акты Российской Федерации» // Coбрание законодательства РФ. 2010. № 31. Ст. 4193.

Федеральный закон от 30.12.2004 № 215-Ф3 (ред. от 23.07.2013) «О жилищных накопительных кооперативах» // Собрание законодательства РФ. 2005. № 1 (часть 1). СT. 41.

Федеральный закон от 30.12.2004 № 210-Ф3 (ред. от 30.12.2012) «Об основах регулирования тарифов организаций коммунального комплекса» // Собрание законодательства РФ. 2005. № 1 (часть 1). Ст. 36. 
дарты раскрытия информации); Федеральный закон «0 естественных монополиях (Статья 8.1. Стандарты раскрытия информации); Федеральный закон «Об инвестиционных фондах» ${ }^{10}$ (Глава XII. Раскрытие информации о деятельности акционерного инвестиционного фонда и управляющей компании паевого инвестиционного фонда); Федеральный закон «0 центральном депозитарии» ${ }^{11}$ (Статья 17. Раскрытие информации о деятельности центрального депозитария); Федеральный закон «O клиринге и клиринговой деятельности» ${ }^{12}$ (Статья 19. Раскрытие информации о деятельности клиринговой организации); Федеральный закон «Об оценочной деятельности в Российской Федерации» ${ }^{13}$ (Статья 22.3. Раскрытие информации саморегулируемой организацией оценщиков); Федеральный закон «О банках и банковской деятельности» ${ }^{14}$ (Статья 8. Раскрытие информации о деятельности кредитной организации, банковской группы и банковского холдинга); Федеральный закон «О несостоятельности (банкротстве)» ${ }^{15}$ (Статья 22.1. Раскрытие информации саморегулируемой организацией арбитражных управляющих); Федеральный закон «0 несостоятельности (банкротстве) кредитных организаций» ${ }^{16}$ (Статья 50.18. Раскрытие информации о ходе конкурсного производства); Федеральный закон «0 водоснабжении и водоотведении» ${ }^{17}$ (Статья 34. Стандарты раскрытия информации в сфере водоснабжения и водоотведения и порядок контроля за соблюдением стандартов

10 Федеральный закон от 29.11.2001 № 156-ФЗ (ред. от 23.07.2013) «Об инвестиционных фондах» // Собрание законодательства РФ. 2001. № 49. Ст. 4562.

Федеральный закон от 07.12.2011 № 414-Ф3 (ред. от 23.07.2013) «О центральном депозитарии» // Собрание законодательства РФ. 2011. № 50. Ст. 7356.

12 Федеральный закон от 07.02.2011 № 7-Ф3 (ред. от 23.07.2013) «О клиринге и клиринговой деятельности» // Собрание законодательства РФ. 2011. № 7. Ст. 904.

13 Федеральный закон от 29.07.1998 № 135-Ф3 (ред. от 23.07.2013) «Об оценочной деятельности в Российской Федерации» // Собрание законодательства РФ. 1998. № 31. Ст. 3813.

14 Федеральный закон от 02.12.1990 № 395-1 (ред. от 30.09.2013) «О банках и банковской деятельности» // Собрание законодательства РФ. 1996. № 6. Ст. 492.

15 Федеральный закон от 26.10.2002 № 127-Ф3 (ред. от 28.12.2013) «О несостоятельности (банкротстве)» // Сoбрание законодательства РФ. 2002. № 43. Ст. 4190.

16 Федеральный закон от 25.02.1999 № 40-ФЗ (ред. от 02.07.2013) «О несостоятельности (банкротстве) кредитных организаций» // Собрание законодательства РФ. 1999. № 9. Ст. 1097.

17 Федеральный закон от 07.12.2011 № 416-Ф3 (ред. от 28.12.2013) «О водоснабжении и водоотведении» // Собрание законодательства РФ. 2011. № 50. Ст. 7358. раскрытия информации); Федеральный закон «0 негосударственных пенсионных фондах» ${ }^{18}$ (Статья 35.3. Требования к содержанию распространяемой, предоставляемой или раскрываемой информации).

Информация, которая подлежит раскрытию в соответствии с приведенными законами, не носит конфиденциального характера в силу нормативных правовых актов. В большинстве случаев это сведения о фирменном наименовании, об уставе, о внутренних документах, сведения о приостановлении действия или об аннулировании лицензии, о назначенных им административных наказаниях, сведения о финансовой отчетности, о правилах этики деятельности и т.п.

Напрямую касающимся рассматриваемого вопроса в сфере информационно-правового обеспечения общественного контроля является Постановление Правительства РФ от 25.08.2012 № 851 «0 порядке раскрытия федеральными органами исполнительной власти информации о подготовке проектов нормативных правовых актов и результатах их общественного обсуждения». Все три признака раскрытия информации присутствуют здесь. Требование нормативного правового акта, доступ к информации о подготовке проектов нормативных правовых актов не ограничен никаким нормативным правовым актом, но не был открыт в силу отсутствия у обладателя убежденности в необходимости сделать эту информацию достоянием гласности, и, наконец, цель обеспечения общественных интересов на лицо.

Также понятие раскрытия информации применяется, когда речь идет об обеспечении доступа к информации о деятельности государственных органов и органов местного самоуправления. Правоотношения здесь регулируется Федеральным законом «Об обеспечении доступа к информации о деятельности государственных органов и органов местного самоуправления» ${ }^{19}$, который термина «раскрытие информации» не включает. Одним из направлений реализации обеспечения доступа к информации, которой обладают органы власти, является концепция открытых данных.

Открытые данные - это информация о деятельности государственных органов и органов

18 Федеральный закон от 07.05.1998 № 75-Ф3 (ред. от 28.12.2013) «О негосударственных пенсионных фондах» // Собрание законодательства РФ. 1998. № 19. Ст. 2071.

19 Федеральный закон от 09.02.2009 № 8-Ф3 «Об обеспечении доступа к информации о деятельности государственных органов и органов местного самоуправления» // Собрание законодательства РФ. 2009. № 7. Ст. 776. 
местного самоуправления, размещенная в сети Интернет в виде массивов данных в формате, обеспечивающем их автоматическую обработку для повторного использования без предварительного изменения человеком (машиночитаемый формат) и на условиях ее свободного (бесплатного) использования ${ }^{20}$.

Специфика информации о деятельности государственных органов и органов местного самоуправления заключается прежде всего в том, что эти органы являются обладателями самого большого объема общественно значимой информации, как правило, включающей в себя другие категории информации, вызывающей повышенный общественный интерес в силу своего влияния на все сферы человеческой деятельности.

Размещение открытых данных позволит повысить прозрачность деятельности органов государственной власти и органов местного самоуправления, что соответствует требованиям общества, движению к реализации в России концепций «открытого правительства» и «электронной демократии».

Использование возможностей сети Интернет во многом должно обеспечить реализацию потребностей в информации максимального числа заинтересованных лиц. Причем важным условием здесь является централизация информационных источников.

Повышение открытости органов власти позволяет достичь сразу нескольких целей. Во-первых, сделать государство более демократичным, информационно открытым для граждан. Во-вторых, повысить эффективность деятельности государственного аппарата. В-третьих, установить общественный контроль над властью.

Только общественный контроль позволяет повысить ответственность государственных и муниципальных служащих за свою деятельность, делает более эффективной борьбу с коррупцией, растратами, со злоупотреблением должностным положением ${ }^{21}$. Право на доступ к информации является ключевым элементом общественного контроля. Важным элементом гражданского общества является обеспечение государством возможности для граждан ознакомиться с той информацией, которая была основанием для принятия органами власти того или иного решения. Должностное лицо, понимая, что информация о его деятельности

\footnotetext{
20 Открытые данные <http://ar.gov.ru/inform otkritost_05_otkritii_dannie/index.html> (последнее посещение - 23 февраля 2014 г.).

21 Терещенко Л. К. Доступ к информации: правовые гарантии // Журнал российского права. 2010. № 10 C. 46-53.
}

будет всеобще доступна, осознает необходимость качественного исполнения своих обязанностей.

Прежде всего в форме открытых данных должны публиковаться следующие сведения:

1) перечень территориальных органов и представительств (представителей) федерального органа власти за рубежом;

2) перечень подведомственных организаций;

3) информация о результатах плановых и внеплановых проверок, проведенных федеральным органом исполнительной власти и его территориальными органами в пределах их полномочий, а также о результатах проверок, проведенных в федеральном органе исполнительной власти, его территориальных органах и подведомственных организациях;

4) статистическая информация, сформированная федеральным органом исполнительной власти в соответствии с федеральным планом статистических работ, а также статистическая информация по результатам проведенных плановых и внеплановых проверок;

5) сведения о вакантных должностях государственной гражданской службы, имеющихся в федеральном органе исполнительной власти и его территориальных органах;

6) реестры лицензий на конкретные виды деятельности, лицензирование которых осуществляется федеральными органами исполнительной власти ${ }^{22}$.

Предоставление сведений о деятельности государственных органов и органов местного самоуправлениях в форме открытых данных позволит использовать их при создании различных информационных систем не только государственного уровня, но и общественных, и частных систем и интернет-ресурсов.

Таким образом, предлагается включить «раскрытие информации» в число форм обеспечения доступа к информации и закрепить в Федеральном законе «Об информации, информационных технологиях и о защите информации» в следующей форме: «Раскрытие информации - это обеспечение ее доступности всем заинтересованным в этом лицам независимо от целей получения данной информации в соответствии с требованием закона».

Правовое понимание того, что собой представляют общественные интересы, поможет

\footnotetext{
22 Распоряжение Правительства РФ от 10.07.2013 № 1187-р «О Перечнях информации о деятельности государственных органов, органов местного самоуправления, размещаемой в сети “Интернет” в форме открытых данных»// Собрание законодательства РФ. 2013. № 30 (часть II). Ст. 4128.
} 
юридически очертить границы общественного контроля как правового явления, базирующегося на праве на доступ к информации.

Таким образом, целесообразно определить общественный интерес как потребность нео- пределенного круга лиц в получении информации со стороны государственных органов или иных обладателей такой информации в целях реализации и защиты охраняемых Конституцией РФ благ и ценностей.

\section{Библиография}

1. Новиков А. В. Контроль в социально-политической системе российского общества. М.: Соврем. Экономика и право, 2005. - 407 с.

2. Пылин В. В., Пылин С. В. Государственный и муниципальный контроль: учеб. пособие СПб.: Изд-во Политехн. ун-та, 2006. - 388 с.

3. Терещенко Л. К. Доступ к информации: правовые гарантии // Журнал российского права. № 10. 2010. - С. 46-53.

\section{References}

1. Novikov A. V. Kontrol' v sotsial'no-politicheskoi sisteme rossiiskogo obshchestva. M.: Sovrem. Ekonomika i pravo, 2005. - 407 s.

2. Pylin V.V., Pylin S. V. Gosudarstvennyi i munitsipal'nyi kontrol': Ucheb. Posobie SPb.: Izd-vo Politekhn. Un-ta, 2006. - $388 \mathrm{~s}$.

3. Tereshchenko L. K. Dostup k informatsii: pravovye garantii // Zhurnal rossiiskogo prava. - № 10. 2010. - S. 46-53. 